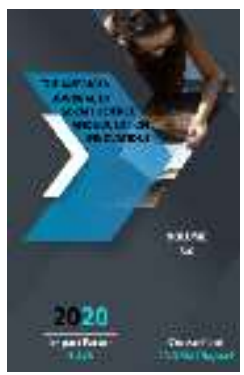

\title{
The Development Of The Preschool Education System Is A Requirement Of The Times
}

\author{
Lola Kuzibaevna Narimbaeva \\ Lecturer, Department Of Preschool Education, Faculty Of Preschool And Primary Education, \\ Chirchik State Pedagogical Institute Of Tashkent Region, Uzbekistan
}

\begin{abstract}
Journal Website: http://usajournalshub.c om/index,php/tajssei

Copyright: Original content from this work may be used under the terms of the creative commons attributes 4.0 licence.
\end{abstract}

\section{ABSTRACT}

This article examines the role of the ongoing work on the development of preschool education in our society, the essence of the laws, decrees and decisions issued by our government, the current needs and recommendations in this regard. The article also provides a number of historical data related to the rich history of the emergence and development of preschool education, as well as the author's suggestions and recommendations.

\section{KEYWORDS}

Preschool, kindergarten, children, reading, worldview, future, national, traditional, coach, educator, organization, information, information.

\section{INTRODUCTION}

According to experts, by the age of 5 , a person receives $70 \%$ of all information and data that he receives during his lifetime. In this case, first of all, the upbringing of parents is of paramount singificant, and at a later stage it has been scientifically proven that the environment in kindergarten is an singificant factor in expanding the worldview, perception of the world by the child.
Therefore, in recent years, large-scale work has been carried out in the preschool education system in our country. In particular, much attention is paid to the development of publicprivate partnerships in this area, to further increase the number of non-state preschool educational institutions, to expand the range of services they provide. The education system in our country is always in the center of attention of the state. Over the past period, comprehensive organizational and legal 
measures have been taken to organize an effective preschool education system aimed at ensuring the formation of a healthy and comprehensively developed generation. The industry is currently in a state of profound reforms.

\section{THE MAIN FINDINGS AND RESULTS}

As noted by the President of the Republic of Uzbekistan Shavkat Mirziyoyev in his report at the enlarged meeting of the Cabinet of Ministers on the main results of socioeconomic development of the country in 2019 and the most important priorities of the economic program for 2020, "Previous meetings have provided a critical analysis of the state of affairs in the field of education and science, the implementation of state youth policy, the introduction of new, modern methods of education, including information and communication technologies. The implementation of urgent tasks in this area is of strategic importance for the future of our youth, our society and our country."

Resolution of the President of the Republic of Uzbekistan dated December 29, 2016 No PD2707 "On measures to further improve the system of preschool education in 2017-2021." Among the main objectives and directions of the "Program for further improvement of the system of preschool education for 2017-2021" approved by this resolution is to create conditions for comprehensive intellectual, moral, aesthetic and physical development of children, taking into account the best international practices.

Further expansion of the state and non-state network of preschool education, creating conditions for a healthy competitive environment between public and private preschool education, introduction of new forms of preschool education in public-private partnership, as well as effective organization of the Ministry of Preschool Education Resolution of the President of the Republic of Uzbekistan dated September 30, 2017 No PP-3305 "On the organization of the activities of the Ministry of Preschool Education of the Republic of Uzbekistan." As noted in the commentary to the decision: "... today the issue of radical improvement of preschool education, increasing the number of preschool children, the creation of a modern system in all respects, studying the best international practices remains relevant" . In order to solve the existing problems of reforming the preschool education system, the decree provides for the implementation of a wide range of measures, including the effective organization of the process of improving the qualifications of teachers and managers, including using modern pedagogical and information technologies, advanced experience of foreign countries, provision of highly qualified, modern qualified personnel.

Here we analyze the preschool education system in the Russian Federation, one of the foreign countries. The system of preschool education in Russia is constantly evolving, it is constantly being updated, changing its appearance and improving. The first teachers for a child are his parents. They must raise children from infancy in physical, intellectual, and moral matters. The activities of pre-school educational institutions (PSE) are aimed at helping families to acquire knowledge and at the next stage of education. Some experts argue that the need for kindergartens is a burden, and that pre-school education should be left entirely to the parents, who should decide for themselves where and how to 
prepare the child for 1st grade. But according to statistics, most parents use the services of PSEs. Therefore, the strategy for the development of the education system identifies the modernization of preschool education in Russia as one of the priority issues in the future. According to the standard regulations, children's educational institutions are divided into five types:

- Kindergartens, which consider it important to implement one or two areas of development;

- Compensatory kindergartens aimed at qualified correction of children with mental disorders;

- Kindergartens under the supervision of educators, where health-improving exercises are conducted with children;

- Kindergartens with general development, rehabilitation and compensatory groups in different variants on their territory;

- Early childhood development centers kindergartens where children can recover, acquire new knowledge and skills, receive spiritual support.

Theoretical studies show that stereotyped approaches to the content of preschool education must be changed, and the educational process should be considered on the basis of the following sequence of principles:

- Teaching based on the developmental nature of teaching reflects the hidden and potential qualities of children;

- Systematic education helps children to identify the interrelationship of events, objects of study and life values;

- The development of the child is based on his emotions and age-appropriate forms of education;
- The essence of multicultural education is to bring children closer to the culture and traditions of their own and other nations and peoples, to be more tolerant of the opinions of others, to express their dissatisfaction, anger and resentment in a moderate way;

- based on the need for a healthy lifestyle, adherence to the rules of hygiene and sports.

It should be noted that the difference between the upbringing and education of children does not exist in all countries. In the UK, however, both are recognized as important and necessary. There are 25 types of institutions in the United Kingdom that provide these services, and therefore the education system is diverse and unequal in importance.

\section{CONCLUSION}

In a word, the purpose of acting on the above suggestions and recommendations is to develop in the child a sense of solidarity, community. When a song is sung, as the great scholar Abū Nașr al Fārābī said, it should be sung by a choir (in a group), a solo singer is not used, when a competition is held, or all or a group wins, and not an individual winner at all. Therefore, if we work together as a team on the development of the preschool education system, we will undoubtedly achieve our goals in the future.

\section{REFERENCES}

1. Resolution of the President of the Republic of Uzbekistan Sh.M.Mirziyoev dated May 8, 
2019 No PP-4312 "On approval of the Concept of development of the system of preschool education of the Republic of Uzbekistan until 2030".

2. Convention on the Rights of the Child // International Acts on Human Rights / Comp. and entered. Art: V.A. Kartashkin, E.A. Lukashev. Moscow: Infra-M, 1998. -p. 306324.

3. Karimov I.A. High spirituality is an invincible force. Tashkent: Spirituality, 2008. - p. 38.

4. Doronova T.N. Preschool institution and family - a single development space: methodological guidance for employees of preschool educational institutions / T.N.Doronova., E.V. Solovieva., A.E. Zhichkina., S.I. Musienko. Moscow: LINKAPRESS, 2001. - p. 5.

5. Khusan Abdurakhimovich Umarov. (2020). Formation of students' professional readiness on the basis of innovative ways of cooperation in the conditions of uzbekistan (by the example of future teachers). Journal of Central Asian Social Studies, 1(01), 15-25. https://doi.org/10.37547/jcass/volume01issu e01-a2

6. Shomirzayev, M. (2020). Developing Educational Technologies In School Technology Education. The American Journal of Engineering and Technology, 2(07), 51-57. https://doi.org/10.37547/tajet/Volume02Issu e07-08 